\title{
An Urban-Regional Employment Demand Model
}

\author{
MICHAEL W. BABCOCK*
}

In his article "An Approach to Metropolitan Employment Forecasting" Richardson pointed out the lag in the development of subnational area economic forecasting behind other branches of economic forecasting. ${ }^{1}$ This seems paradoxical in view of the need for such models in formulating public policy. The regional impact of federal expenditure programs, the formulation of local economic policy, and the adoption of rational education policies represent problem areas which need a local economic forecasting system as an information input.

In the article cited above, Richardson discussed the limitations of the existing local forecasting techniques, so I will only briefly review them here. The existing techniques include (1) naive models, (2) export base models; and (3) input-output models. The naive models, usually involve trend extrapolation of some variable such as regional employment, income, or output. These models may result in reasonably accurate forecasts in the short run, but yield very poor long run forecasts since they blindly project the past. The major weakness of export base models for prediction purposes is the dynamic instability of the base-service ratio. The fundamental drawbacks of input-output models are the well known empirical implementation obstacles. These include obtaining the regional interindustry coefficients matrix, which implies that the researcher must generate his own data by some type of survey method. Non-survey techniques designed to simulate regional interindustry coefficients have so far met with only modest success. $^{2}$ Another difficult problem is the development of techniques to forecast regional final demand.

The local employment demand model presented in this paper was developed at the Center of Advanced Computation, University of Illinois as part of a manpower and educational forecasting system known as STEP I. The industry employment demand model served as a basis for detailed occupational demand forecasts for the state of Illinois. ${ }^{3}$ Thus the model presented here is a local industry employment demand model. As Richardson has pointed out, the output of such a model, a vector of forecast industry employment, can serve as an important first step in forecasting other economic information such as occupational demand, income distribution, and net migration. ${ }^{4}$ The results of the Illinois study are presented for illustrative purposes, but the application of the model to metropolitan areas will be discussed.

\section{THE MODEL}

In the development of the theory of regional growth, demand has received far more attention than supply. The existing subnational area employment fore-

\footnotetext{
*Assistant Professor, Department of Economics, Kansas State University, Manhattan, Kansas.
} 
casting techniques also emphasize demand. The export base theory emphasizes the importance of developing a strong, diversified, industrial base. The base industries, which export to the rest of the world, provide the growth force since they induce increases in income and employment in industries which are primarily influenced by the strength of local demand. So the export base forecasting technique seeks to (1) forecast the growth in employment of the base industries; and (2) estimate the impact on total employment by use of a base multiplier. Interregional input-output models also emphasize demand since the forecast of the final demand vector is the crucial step in obtaining the forecast industry output or employment. The forecast of national and international exports is particularly important, especially for a region as small as a metropolitan area.

Other theories of regional growth have stressed supply considerations. The availability and price of local inputs such as labor, land, public services, business services, and the external economies of industrial complexes are some of the supply variables which are thought to influence regional growth. The price and availability of such local inputs have an important bearing on the locational attractiveness of the area to new firms and expanding older firms. Thus supply considerations may have an important impact on the ability of a region to compete for new industry. Richardson's metropolitan employment forecasting model has sought to incorporate the effect of some of these supply factors as well as the recognition of the importance of national and international demand. In this sense, the Richardson model is a significant departure from the existing demand oriented techniques.

In formulating the model used in the Illinois study, the primary consideration was the predictive ability of the model. Most would agree that the two major goals of scientific inquiry are explanation and prediction. Unfortunately the two goals are often mutually exclusive. Very sophisticated models, which appear to explain the nature of economic reality very well, often prove to be impossible to implement empirically due to unavailability or non-conformability of data. In contrast, simple models which contribute little to an understanding of the interrelationships of economic variables, sometimes appear to do an accurate job of predicting the magnitudes of certain economic variables, once the values of other variables are estimated. The principal objective of the Illinois study was to forecast industry employment demand as a necessary first step in obtaining detailed occupational employment demand forecasts. Thus no attempt was made to empirically determine the relative importance of the various supply and demand variables which influence regional growth. Given the objectives of the study, the Friedmanesque emphasis on prediction as the major goal of theory was adopted.

The model emphasizes the role of demand, especially the nature of national and international demand in determining regional employment change. The model hypothesizes that a set of national priority choices, determined by a political process, leads to a certain pattern of demand for the output of the various industries in the national economy. The demand for industrial output implies a derived demand for labor which leads to a certain pattern of national industrial employment. This pattern of national demand will have favorable or adverse employment effects on the region depending on its existing industrial structure. The 
pattern of national demand thus implies a certain regional industrial distribution of employment.

The regional industry employment forecasting model is of the following form: ${ }^{5}$

$\begin{array}{ll}\mathrm{E}(\mathrm{REGIND})_{\mathrm{i}}=\mathrm{B}_{0}+\mathrm{B}_{1} \mathrm{E}(\mathrm{UST})+\mathrm{B}_{2} \mathrm{E}(\mathrm{USI})_{\mathrm{i}}+\mathrm{B}_{3} \mathrm{EX}+\mathrm{B}_{4} \mathrm{E} \text { (REGT) } & +\mathrm{B}_{5} \mathrm{t} \\ \mathrm{E}(\mathrm{REGIND})_{\mathrm{i}} & - \text { Total private wage and salary employment in the } \mathrm{i} \text { th region- } \\ & \quad \text { al industry. } \\ \mathrm{E}(\mathrm{UST}) & - \text { Total U.S. private wage and salary employment } \\ \mathrm{E}(\mathrm{USI})_{\mathrm{i}} & - \text { Total private wage and salary employment in the } \mathrm{i} \text { th indus- } \\ & \quad \text { try in the U.S. } \\ \mathrm{EX} & - \text { Total U.S. merchandise exports } \\ \mathrm{E}(\mathrm{REGT}) & - \text { Total regional private wage and salary employment. } \\ \mathrm{t} & - \text { Time }\end{array}$

This regression equation was estimated for each industry in the industrial classification system of the Illinois study. ${ }^{6}$ The 2 digit level of the Standard Industrial Code (SIC) was used as the classification scheme. The first three independent variables indicate the emphasis on the strength and nature of demand external to the region. Independent variable $\mathrm{E}(\mathrm{USI})_{\mathrm{i}}$, and to some extent variable $\mathrm{E}$ (UST), incorporate the effect of the pattern of national industrial demand on the individual industries of the region. Independent variable EX measures the strength of international demand for local output. Ideally, merchandise exports of each local industry should be used in the model rather than the gross measure of total U.S. exports, but this is impossible because data are lacking. Detailed export statistics are not available by industry group and state. The export statistics published by the U.S. Department of Commerce in the Survey of Current Business are published for the entire U.S. and by commodity groups. Independent variable E (REGT) was included in an attempt to incorporate the effect of local demand on regional production. The time variable was included in the multiple regression model as a proxy variable for other influences on regional industrial employment which cannot yet be quantified or forecast. The time variable could reflect the effects of differential technical progress on employment in the regional industries. It could also reflect other factors affecting employment such as shifts in regional wage differentials, or other regional input cost changes.

It is recognized that employment data is an imperfect measure of national, international, and local demand. However, this theoretical shortcoming is also an important empirical advantage since the regional industry employment model can be linked to any national submodel that can provide forecast values of the independent variables $\mathrm{E}(\mathrm{UST}), \mathrm{E}(\mathrm{USI})_{\mathrm{i}}$, and $\mathrm{EX}$.

\section{RESULTS OF THE MODEL - STATE OF ILLINOIS}

The above industry regression model was estimated for 60 Illinois industries using the 2 digit SIC classification. The time period used to estimate the state regressions was 1958-1969. This period was selected since the SIC was revised in 1957. Using data from years prior to 1958 would have involved very costly, sub- 
stantial revision of the data in many industries. Data for independent variables E(REGIND) and E(REGT) was obtained primarily from Employment and Earnings Statistics-States and Areas 1909-1969 and County Business Patterns.? The data for independent variables E(UST) and E(USI) was taken from Employment and Earnings Statistics for the United States 1909-1970 and also County Business Patterns. ${ }^{8}$ Data for independent variable EX was obtained from the Survey of Current Business. ${ }^{9}$ Secondary reliance was placed on a variety of other sources where minor data gaps existed in the primary sources.

The $\mathrm{R}^{2}$ statistic for each of the 60 industrial regression equations is found in the first column of Table I. The fit of the regression is quite good in virtually all the industries. The $\mathrm{R}^{2}$ statistic is greater than .90 in 54 of the 60 industries and greater than .99 in 24 industries. The notable exceptions are Stone, Clay, and Glass Products (32); Water Transportation (44); Pipeline Transportation (46); and Real Estate (65) with $\mathrm{R}^{2}$ 's of $.78, .66, .70$, and .76 respectively.

\section{TABLE I}

MODEL RESULTS AND ACCURACY TEST

STATE OF ILLINOIS - 1970

(000) employees

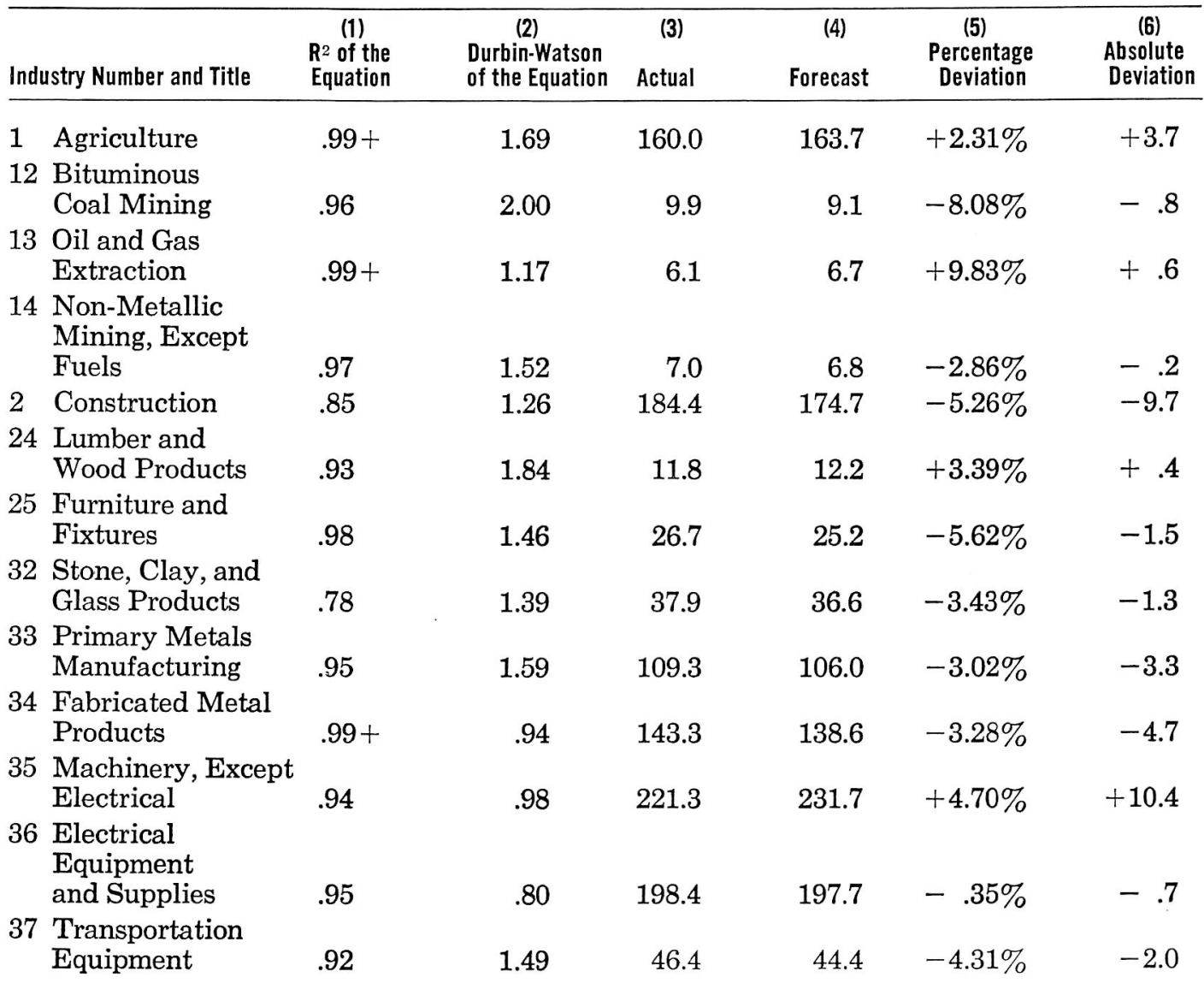




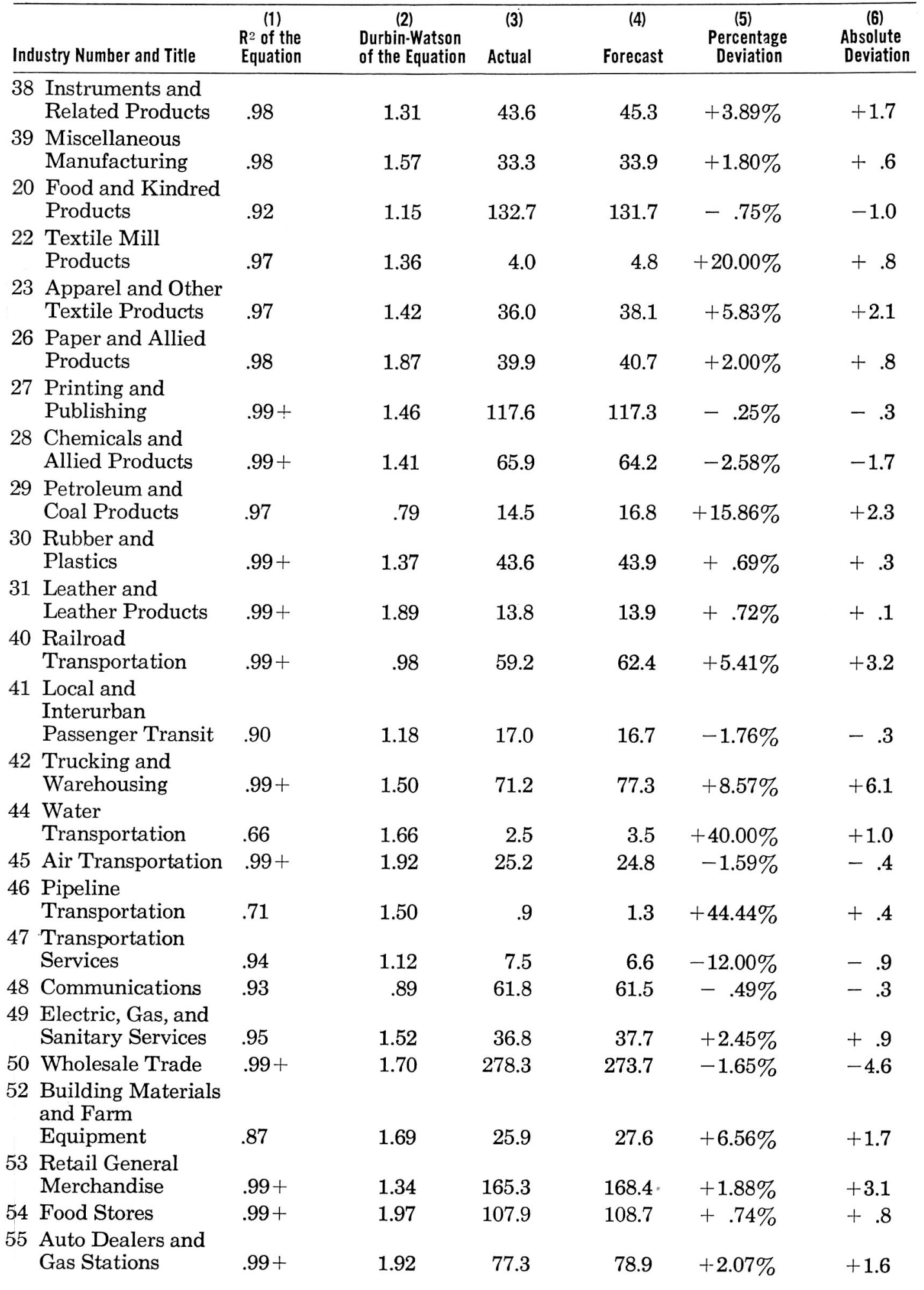




\begin{tabular}{|c|c|c|c|c|c|c|}
\hline Industry Number and Title & $\begin{array}{c}\text { (1) } \\
R^{2} \text { of the } \\
\text { Equation }\end{array}$ & $\begin{array}{l}\text { (2) } \\
\text { Durbin-Watson } \\
\text { of the Equation }\end{array}$ & $\begin{array}{c}\text { (3) } \\
\text { Actual }\end{array}$ & $\begin{array}{c}\text { (4) } \\
\text { Forecast }\end{array}$ & $\begin{array}{c}\text { (5) } \\
\text { Percentage } \\
\text { Deviation }\end{array}$ & $\begin{array}{c}\text { (6) } \\
\text { Absolute } \\
\text { Deviation }\end{array}$ \\
\hline \multicolumn{7}{|l|}{56 Apparel and } \\
\hline Accessories & .98 & 1.82 & 44.1 & 44.6 & $+1.13 \%$ & +.5 \\
\hline \multicolumn{7}{|l|}{57 Furniture and } \\
\hline Home Furnishings & $.99+$ & 1.67 & 24.4 & 25.4 & $+4.10 \%$ & +1.0 \\
\hline \multicolumn{7}{|l|}{58 Eating and } \\
\hline Drinking Places & .92 & 1.66 & 147.3 & 139.2 & $-5.50 \%$ & -8.1 \\
\hline \multicolumn{7}{|l|}{59 Miscellaneous } \\
\hline Retail Stores & .97 & 1.61 & 68.9 & 75.0 & $+8.85 \%$ & +6.1 \\
\hline 60 Banking & $.99+$ & 1.93 & 61.3 & 61.8 & $+.82 \%$ & +.5 \\
\hline \multicolumn{7}{|l|}{61 Credit Agencies } \\
\hline Other Than Banks & $.99+$ & 1.68 & 22.7 & 23.9 & $+5.29 \%$ & +1.2 \\
\hline \multicolumn{7}{|l|}{62 Security, } \\
\hline $\begin{array}{l}\text { Commodity Brokers } \\
\text { and Service }\end{array}$ & .98 & 1.89 & 11.4 & 11.4 & 0 & 0 \\
\hline 63 Insurance Carriers & $.99+$ & 1.32 & 71.5 & 72.0 & $+.70 \%$ & +.5 \\
\hline \multicolumn{7}{|c|}{64 Insurance Agents, } \\
\hline \multirow{2}{*}{$\begin{array}{l}65 \text { Real Estate } \\
70 \text { Hotels and Other } \\
\text { Lodging Places }\end{array}$} & .76 & 1.87 & 47.3 & 55.3 & $+16.91 \%$ & +8.0 \\
\hline & .97 & .97 & 37.0 & 36.9 & $-.27 \%$ & -.1 \\
\hline $\begin{array}{l}72 \text { Personal Services } \\
73 \text { Miscellaneous }\end{array}$ & \multicolumn{5}{|c|}{73 Miscellaneous } & -.2 \\
\hline $\begin{array}{l}\text { Business Services } \\
75 \text { Auto Repair }\end{array}$ & $.99+$ & 1.61 & 102.9 & 101.4 & $-1.46 \%$ & -1.5 \\
\hline \multicolumn{7}{|l|}{76 Miscellaneous } \\
\hline Repair Services & $.99+$ & 1.51 & 10.3 & 10.3 & 0 & 0 \\
\hline $\begin{array}{l}78 \text { Motion Pictures } \\
79 \text { Amusement, }\end{array}$ & .95 & 1.60 & 9.2 & 9.2 & 0 & 0 \\
\hline $\begin{array}{l}\text { Recreation, exc. } \\
\text { Motion Pictures }\end{array}$ & .98 & 1.99 & 25.0 & 25.7 & $+2.80 \%$ & +.7 \\
\hline \multicolumn{7}{|l|}{80 Medical and Other } \\
\hline Health Services & .98 & 1.07 & 180.1 & 186.5 & $+3.55 \%$ & +6.4 \\
\hline 81 Legal Services & $.99+$ & 1.67 & 14.4 & 14.7 & $+2.08 \%$ & +.3 \\
\hline \multicolumn{7}{|c|}{82 Education Services- } \\
\hline Public & $.99+$ & 1.88 & 264.6 & 252.4 & $-4.60 \%$ & -12.2 \\
\hline \multicolumn{7}{|l|}{$86 \begin{array}{l}\text { Non-Profit } \\
\text { Membership }\end{array}$} \\
\hline Organizations & $.98+$ & 1.37 & 73.7 & 76.5 & $+3.80 \%$ & +2.8 \\
\hline \multicolumn{7}{|l|}{89 Miscellaneous } \\
\hline Services & .96 & 1.50 & 39.3 & 39.4 & $+.25 \%$ & +.1 \\
\hline Total* & & & 3669.5 & 3692.2 & $+.62 \%$ & +22.7 \\
\hline
\end{tabular}

*The Total figure given is the total for the non-agricultural, private industries used in the Illinois industry classification system. Total Illinois non-agricultural, private wage and salary employment for 1970, which is 3857.6, includes some industries which are not in the industry classification used in this study due to insignificant Illinois employment or a lack of data.

**Data source for actual industry employment - Employment, Hours, and Earnings in Illinois - 1969 and 1970 published by Illinois Department of Labor, Bureau of Employment Security. 
Column (2) of Table I displays the Durbin-Watson coefficients for each of the regression equations. There is no significant autocorrelation in any of the equations. The Durbin-Watson statistics of some of the equations fell in the inconclusive range of the 1\% Durbin-Watson limits but the majority of the DurbinWatson statistics exceeded the upper limit.

There was a relatively high degree of multicollinearity present in most of the equations, which made identification of the precise structural parameters impossible. However, the existence of multicollinearity in the sample period does not present a serious obstacle to the primary objective of a forecasting model which is prediction. The predictive viability of the equations will remain intact as long as the multicollinearity continues into the prediction period. ${ }^{10}$

To test the predictive ability of the model an accuracy test was performed for the year 1970. The actual magnitudes of each independent variable in 1970 were inserted into the regression equations and a "forecast" value of wage and salary employment in each Illinois industry was obtained. These "forecast" values, which are found in column (4) of Table I, were then compared to the actual values of wage and salary employment in each industry which are found in column (3) of Table I. The overall performance of the model was good. In 50 of the 60 industries the percentage error was less than 6\%. In 24 industries the percentage error was less than $2 \%$. The largest percentage errors occurred in industries with relatively small employment such as Textile Mill Products (22); Water Transportation (44); and Pipeline Transportation (46). This is not too surprising since the closing of a single plant, the in-migration of a single plant, or a prolonged strike could lead to a large percentage error which could not be predicted using the regression technique.

\section{APPLICATION OF THE MODEL TO METROPOLITAN AREAS}

One method of forecasting employment change for metropolitan areas or SMSAs is to disaggregate the forecasts for a larger region such as a state. However, this method may result in greater forecast error than forecasting the growth of the SMSA directly since the disaggregation procedure involves development of some technique for forecasting the metropolitan area's share of the employment growth of the larger region. Thus if it is assumed that the sources of error in the model would be approximately the same for any size region, the process of regionally disaggregating forecasts made for a larger region would involve greater forecast error than applying the model directly to the smaller region.

The use of the model presented above to develop employment forecasts for SMSAs is constrained by data availability. Unless the SMSA is very large, the industry employment data is available only for very highly aggregated industry categories. The aggregation of the employment forecasts into a few large industry categories greatly limits the usefulness of the forecasts for planning purposes and may lead to misleading policy conclusions.

In addition to the industry employment data being highly aggregated for the smaller SMSAs, employment data of some of the major firms in the SMSA 
may not be reported at all, if there are only a few local firms in the industry, due to the disclosure rules of the major data collecting agencies.

It was noted in the previous section that the largest percentage forecast errors occurred in Illinois industries with relatively small employment. One reason for this could be the loss or gain of a few firms, which can't be predicted from past trends. The same problem would arise in attempting to forecast industry employment in a small SMSA. The loss or gain of a few major industrial employers would lead to large forecast errors for the smaller SMSAs. However, in the case of the larger SMSAs, the industry employment data is available in significant detail. Also the inmigration or outmigration of a few large industrial employers would not introduce as serious a forecast error as would be the case in many of the smaller SMSAs. Thus the predictive viability of the model is greatly influenced by the size of the local labor market.

\section{THE RELATIONSHIP OF ECONOMIC FORECASTS TO ECONOMIC POLICY}

In relating economic forecasts to economic policy it should be emphasized that all economic forecasts are conditional. In order to make a forecast, the analyst will often utilize an econometric model which, if it's a good model, accurately describes the interrelationship of economic variables in the past. A forecast is made using the model by assuming that certain economic variables have given values at some future point in time. Given these future values of some of the variables, forecasts of the magnitude of other variables can be obtained. However, the accuracy of the forecast is conditioned on the degree of coincidence between the assumed future values of certain variables and the eventual actual values of these variables. Thus it is possible for several different economists, using the same model, to obtain widely divergent economic forecasts simply because they have different perceptions of the future. Each of their respective forecasts are conditional in the sense that they depend on the assumptions made concerning the future values of certain economic variables. So the conditional nature of all economic forecasts should be recognized, and no forecast should be regarded as immutable truth.

For example, the model presented above has been used to develop forecasts of industry and occupational demand for the state of Illinois for 1975 and $1980 .^{11}$ Four sets of forecasts were made, each corresponding to a different assumed pattern of national expenditure. One of these patterns of national demand was the Bureau of Labor Statistics forecast of national industrial employment. ${ }^{12}$ The BLS forecasts were developed using the following general assumptions: (1) economic, social, and scientific trends will continue about the same as in the recent past; (2) the institutional framework of the economy will not change radically; (3) values placed on work, income, and leisure will not change drastically; (4) fiscal and monetary policies will be generally successful in achieving a satisfactory balance between unemployment and inflation without reducing the long term economic growth rate; (5) the Vietnam War will have ended by 1975 and the U.S. will not become engaged in any other wars in this decade; (6) fertility rates will be lower than they have been in recent years. ${ }^{13}$ 
Three other forecasts of the pattern of national demand were obtained from the national input-output model developed at the Center of Advanced Computation, University of Illinois. These alternative forecasts of the pattern of national expenditure were made by first forecasting GNP and then assuming alternative distributions of expenditure among the final demand sectors of the model. The three assumed patterns of national demand were the "Status Quo" distribution, corresponding to a "most likely" set of assumptions concerning the distribution of national expenditure; a "Social Welfare" alternative, corresponding to an increase in domestic welfare programs at the expense of defense expenditures; and a "Silent Majority" alternative, emphasizing defense programs and select types of investment activities.

These alternative assumptions regarding the pattern of national demand produced large variation in the employment demand forecasts of many Illinois industries. ${ }^{14}$ Thus it seems legitimate to say that in view of the general sensitivity of local employment to the pattern of national demand, that the accuracy of the forecasts will depend on the analyst's ability to forecast the pattern of national expenditure. Since it is generally impossible to accurately foresee future national priorities in the present, it follows that the most rational approach to regional employment forecasting is the conditional approach. By making several alternative assumptions concerning the nature of national demand, a range of employment estimates can be obtained giving the direction of and probable degree of change in employment in response to given patterns of national expenditure. This procedure may not simplify the policy maker's task, but it recognizes forecasts for what they are-tools for decision making, not applied clairvoyance.

\section{FOOTNOTES}

1H. W. Richardson, "An Approach to Metropolitan Employment Forecasting," Review of Regional Studies, Vol. II (Spring, 1972), pp. 13-27.

2W. A. Schaffer, "Estimating Regional Input-Output Coefficients," Review of Regional Studies, Vol. II (Spring, 1972), pp. 57-71.

3M. W. Babcock, Employment Implications of Alternate Federal Spending Priorities for the Illinois Economy, unpublished Ph.D. thesis, Urbana, Ill., 1973.

4See Richardson, op. cit., p. 13.

5 Wage and salary data had to be used since no total employment time series data exists for a detailed classification of industries. However, total employment can be forecast in each state industry by using total employment/wage and salary employment ratios. These ratios can be obtained from the Census of Population which publishes class of worker data by detailed industry for both states and SMSAs. The forecast private wage and salary employment obtained from each regression equation is then multiplied by the appropriate ratio to obtain total industry employment.

${ }_{6}^{6}$ Exports was excluded from the equations of state industries which obviously do not export goods and services outside the U.S. This includes all state industries except those found in the agriculture, mining, and manufacturing sectors.

7U.S. Department of Labor, Bureau of Labor Statistics, Employment and Earnings Statistics - States and Areas 1909-1969, (Washington, D. C.: U.S. Government Printing Office, 1971).

U.S. Department of Commerce, County Business Patterns, editions from 1957 to 1969, (Washington, D. C.: U.S. Government Printing Office).

8U.S. Department of Labor, Bureau of Labor Statistics, Employment and Earnings Statistics for the United States 1909-1970, (Washington, D. C.: U.S. Government Printing Office, 1971).

${ }^{U}$ U.S. Department of Commerce, Office of Business Economics, Survey of Current Business, various issues 1959-1970.

10H. Thiel, Economic Forecasts and Policy (Amsterdam: North Holland Publishing Co., 1965) pp. 355-357.

11See Babcock, op. cit., pp. 93-225. 
12U.S. Department of Labor, Bureau of Labor Statistics, Tomorrow's Manpower Needs. Vol. IV, (Washington, D. C.: U.S. Government Printing Office, 1969).

13 Ibid., p. 4.

14See Babcock, op. cit., pp. 93-99.

\section{REFERENCES}

Bezdek, R. H., Manpower Implications of Alternate Patterns of National Demand for Goods and Services, (Ph.D. thesis, Urbana, Ill., 1971).

Hirsch, W., "Interindustry Relations of a Metropolitan Area," Review of Economics and Statistics, November, 1959.

Leontief, W. W., Morgan, A., Polenske, K., Simpon, D., and Tower, E., "The Economic Impact, Industrial and Regional, of an Arms Cut." The Review of Economics and Statistics, August, 1965.

Richardson, H. W., "An Approach to Metropolitan Employment Forecasting," Review of Regional Studies, Spring, 1972.

Tiebout, C. M., “An Empirical Regional Input-Output Projection Model: The State of Washington 1980." Review of Economics and Statistics, August, 1968.

Udis, B., ed., Adjustments of the U.S. Economy to Reductions in Military Spending. (Washington, D. C.: U.S. Government Printing Office, 1970). 